\title{
Perkawinan Bawah Umur dan Potensi Perceraian (Studi Kewenangan KUA Wilayah Kota Bogor)
}

\author{
Ani Yumarni dan Endeh Suhartini \\ Fakultas Hukum Universitas Djuanda Bogor \\ Jln. Toll Ciawi No. 1 Ciawi Bogor Jawa Barat \\ ani.yumarni@unida.ac.id; endeh.suhartini@unida.ac.id
}

Received: 24 Januari 2018; Accepted: 21 Desember 2018; Published: 24 April 2019

DOI: 10.20885/iustum.vol26.iss1.art10

\begin{abstract}
This study examines: first the authority of VAT on Religion Affair Office (KUA) in Sub district of Bogor City Region in creating an orderly administration of registering the underage marriages, and secondly the assessment of the relevance of underage marriage with the high divorce rates in Bogor City Region. This is an empirical juridical research. From the results of this research, it can be concluded that, first, the VAT Institution in Bogor City has made some maximum efforts to create the orderly marital administration as mandated by law. It is also reaffirmed by the Circular of the Ministry of Religion of RI regarding the implementation of the Marriage Administration System (SIMKAH), which increasingly narrows the space for people to do an underage marriage. Second, the prevalence of underage marriage has the relevance to the high divorce rate also dominated by couples aged 21-30 years. It is because even if the marriage is 'not registered', due to being underage according to the law, it still has an opportunity to obtain legality through legal action to submit a marriage permit application in the Religious Court. In addition, emotional immaturity and household unpreparedness are the factors of high divorce among young couples undergoing an underage marriage.
\end{abstract}

Keywords: VAT - KUA; underage marriage; divorce

\begin{abstract}
Abstrak
Penelitian ini mengkaji: pertama kewenangan PPN pada KUA Kecamatan di Wilayah Kota Bogor dalam menciptakan tertib administrasi pencatatan perkawinan bawah umur, dan kedua mengkaji relevansi antara perkawinan bawah umur dengan tingginya angka perceraian di Wilayah Kota Bogor. Penelitian ini merupakan penelitian yang bersifat yuridis empiris. Hasil penelitian ini menyimpulkan: pertama, Lembaga PPN di Kota Bogor telah berupaya maksimal guna terciptanya tertib administrasi perkawinan sebagaimana yang diamanahkan undang-undang. Dipertegas dengan Edaran Kementerian Agama RI perihal pemberlakuan Sistem Administrasi Nikah (SIMKAH), yang semakin mempersempit ruang gerak masyarakat melakukan perkawinan bawah umur. Kedua, maraknya perkawinan bawah umur, memiliki relevansi dengan tingginya angka perceraian yang juga didominasi pasangan berusia 21 - 30 tahun, karena kalaupun perkawinan tersebut 'tidak dicatat', disebabkan tidak cukupnya umur menurut undangundang, masih memberikan peluang untuk memperoleh legalitas yaitu dengan adanya upaya hukum untuk mengajukan permohonan istbat nikah di Pengadilan Agama. Selain itu, ketidakmatangan emosi dan ketidaksiapan berumahtangga menjadi sebab tingginya perceraian di kalangan pasangan muda yang menjalani perkawinan bawah umur.
\end{abstract}

Kata-kata Kunci: PPN - KUA; perkawinan bawah umur; perceraian 


\section{Pendahuluan}

Bawah umur adalah kiasan bagi orang yang belum dewasa, yaitu anak. Yang menurut Hukum Islam, anak adalah orang yang belum mencapai aqil dan baligh (cakap dan dewasa), maka baginya belum masuk kepada kategori mukallaf, yaitu seseorang yang sudah dapat dibebankan padanya ganjaran atas amalan, pahala dan dosa. Hal ini berkaitan erat dengan ahkamul khamsah ${ }^{1}$ dalam kaidah hukum Islam. Perkawinan bawah umur berarti perkawinan yang dilaksanakan oleh pasangan yang belum mencapai aqil-baligh. Dalam konteks hukum Indonesia, perkawinan bawah umur dilakukan oleh pasangan yang belum mencapai usia 19 tahun bagi laki-laki dan 16 tahun bagi mempelai perempuan. ${ }^{2}$ Perkawinan bawah umur ini marak terjadi di berbagai negara di dunia, salah satunya di Indonesia.

Berdasarkan hasil survei yang dilaksanakan oleh Badan Pusat Statistik (BPS) sebagai hasil kerjasama dengan United Nations Children's Fund (UNICEF), dengan menggunakan sumber data utama yaitu Survei Ekonomi Nasional (Susenas) 20082012 dan Sensus Penduduk (SP) 2010 perihal kehidupan anak-anak perempuan di Indonesia, menyatakan bahwa, prevalensi perkawinan usia anak telah mengalami penurunan lebih dari dua kali lipat dalam tiga dekade terakhir. Data ini menunjukkan bahwa angka perkawinan anak di Indonesia tergolong masih merupakan salah satu yang tertinggi di kawasan Asia Timur dan Pasifik. Data Perkawinan Usia Anak di Indonesia menunjukkan bahwa di antara perempuan pernah kawin usia 20-24 tahun, 25\% menikah sebelum usia 18 tahun menurut Survei Sosial dan Ekonomi Nasional (Susenas) pada 2012. Sementara itu, berdasarkan Survei Demografi dan Kesehatan Indonesia (SDKI) 2012, 17 persen perempuan pernah kawin usia 20-24 tahun menikah sebelum usia 18 tahun. Indonesia merupakan salah satu contoh dari kemajuan global menuju penghapusan praktik perkawinan usia anak dengan penurunan prevalensi lima persen antara SDKI yang diterbitkan di antara 2007 dan 2012. Akan tetapi, tren prevalensi perkawinan usia anak di tingkat daerah dan perbandingannya dengan prevalensi nasional, masih sedikit diketahui atau dipublikasikan. ${ }^{3}$

\footnotetext{
${ }_{1}$ Abkeamul Khamsah adalah 5 (lima) hukum yang dilahirkan dari Hukum Islam. lihat Muhammad Daud Ali, Hukum Islam; Pengantar Ilmu Hukum dan Tata Hukum Islam di Indonesia, Cet. Ke-VIII, Raja Grafindo Persada, Jakarta, 2000, hlm. 39.

2 Pasal 7 ayat (1) Undang-Undang No. 1 Tahun 1974 tentang Perkawinan

${ }_{3}^{3}$ Subdirektorat Statistik Rumah Tangga, Kemajuan yang Tertunda: Analisis Data Perkawinan Usia Anak di Indonesia, Badan Pusat Statistik Indonesia, Jakarta, 2015, hlm. i
} 
Data dari Pusat Kajian Gender dan Seksualitas Indonesia 2015 menyebutkan, Indonesia berada di peringkat kedua di kawasan Asia Tenggara dengan angka pernikahan dini yakni sekitar dua juta dari 7,3 juta perempuan Indonesia di bawah umur 15 tahun. Untuk Jawa Barat menempati urutan keenam dari 34 provinsi dengan angka pernikahan dini. Salah satunya Kota Bogor dengan usia pernikahan dini yang sangat tinggi. ${ }^{4}$

Kasus perceraian di Pengadilan Agama di seluruh Indonesia sepanjang 2011 mencapai angka yang tinggi. Jumlah suami dan istri yang mengajukan perceraian sebanyak 314.615 perkara dengan rincian; cerai talak 99.599 (27,40\%) dan cerai gugat sebanyak 215.368 (59,25\%) sedangkan untuk tahun 2012 sebanyak 346.478 perkara dengan rincian; cerai talak sebanyak 107.805 (26,63\%) dan cerai gugat sebanyak 238.673 (58,95\%). ${ }^{5}$ Di Provinsi Jawa Barat dengan luas $35.377,76 \mathrm{~km}^{2}$ yang didiami sebanyak 46.169 .600 penduduk memiliki tingkat perceraian sangat tinggi dari tahun ke tahun. Perbandingan pada 2013 hingga Oktober 2014 mengalami tingkat angka perceraian hampir mencapai 10\% dibanding jumlah pernikahan. Di mana salah satu penyebabnya yaitu pernikahan usia dini. Perceraian banyak terjadi pada pasangan muda dengan usia pernikahan kurang dari 10 tahun. Dikarenakan banyaknya pernikahan usia dini di Jawa Barat, sehingga menyumbang terjadinya perceraian. ${ }^{6}$

Khusus di Kota Bogor, fenomena sosial yang muncul akhir-akhir ini adalah tingginya angka perkawinan yang dilakukan oleh pasangan usia dini atau bawah umur. ${ }^{7}$ Betapa tidak, tingkat pernikahan dan kehamilan di usia 16-19 tahun cukup mencengangkan. Pada 2013 terdapat 1.626 pasangan yang melakukan pernikahan usia dini. Data yang dihimpun Radar Bogor, setahun yang lalu tercatat 8.130 pasangan yang menikah. Dimana 20\% dari jumlah tersebut menikah di usia 19-20 tahun. Kepala Seksi (Kasi) Bimbingan Masalah Islam (Bimas Islam) Kemenag Kota

\footnotetext{
${ }^{4}$ Ibid.

${ }^{5}$ Ramdani Wahyu Sururie, "Kekuatan Pembuktian Testimonium De Audito dalam Perkara Perceraian (Kajian Putusan Nomor 0141/Pdt.G/2011/PA.Krw dan Nomor 16/Pdt.G/2012/PTA. Bdg)", Jurnal Yudisial, Vol. 7 No. 2 Tahun 2014, hlm. 137 - 155

${ }^{6}$ Disampaikan oleh Abdurrahim, Kepala Subbag Humas Kanwil Kemenag Provinsi Jawa Barat, dalam Seminar "Pendewasaan Usia Perkawinan", di Bandung, pada tanggal 26 Juni 2014. Diakses pada laman www.bimasislam.kemenag.go.id

7 “1.626 Remaja Bogor Nikah Dini” diakses melalui https://www.jpnn.com/daerah/jabar 09 Maret 2014
} 
Bogor, Sufyan Suri mengatakan bahwa selain dikarenakan telah terjadi kehamilan sebelum perkawinan berlangsung, pernikahan dini juga dikarenakan rendahnya tingkat pendidikan yang biasanya pernikahan itu dilakukan di perkampungan. Dari pengakuan beberapa calon pasangan bahkan mereka menikah tanpa sepengetahuan orang tua mereka.

Pengaturan normatif terkait dengan pernikahan dirumuskan di dalam Pasal 1 UU Nomor 1 Tahun 1974 tentang Perkawinan, bahwa "perkawinan adalah ikatan lahir batin antara seorang lelaki dengan seorang perempuan untuk membentuk rumah tangga (keluarga) yang bahagia dan kekal berdasarkan Ketuhanan Yang Maha Esa.” Selanjutnya QS. An-Nisa': 4 menyatakan: “Dan mereka (istri-istrimu) telah mengambil dari kamu perjanjian yang kuat." Perkawinan adalah perjanjian yang kuat, disebut dengan kata-kata 'mitsaqan ghaalidzan'.

Menurut UU Nomor 1 Tahun 1974 Pasal (2) disebutkan bahwa "perkawinan adalah sah apabila dilakukan menurut hukum masing-masing agamanya," kemudian mengenai pencatatannya diatur dalam PP Nomor 9 Tahun 1975 yaitu “pencatatan perkawinan dari mereka yang melangsungkan perkawinannya menurut agama Islam, dilakukan oleh PPN sebagaimana dimaksud dalam UU Nomor 32 Tahun 1954 tentang Pencatatan Nikah, Talak, dan Rujuk. ${ }^{8}$ Sehingga, Peradilan Agama dalam hal perkawinan mempunyai kewenangan absolut mengenai proses perceraian dan pencatatannya, sedangkan pengawasan dan pencatatan perkawinannya merupakan kewenangan Kantor Urusan Agama $(\mathrm{KUA})^{9}$ yang dikepalai oleh Pegawai Pencatat Nikah. ${ }^{10}$

Menurut Neng Djubaidah,11 yang dimaksud dengan "pencatatan perkawinan" adalah pencatatan atas perkawinan yang sah menurut Hukum Islam, yaitu perkawinan yang memenuhi rukun dan syarat perkawinan sesuai syariah Islam yang dilakukan di KUA setempat. Adapun yang dimaksud "perkawinan

${ }^{8}$ Jaih Mubarok (ed.), Peradilan Agama di Indonesia, Pustaka Bani Quraisy, Bandung, 2004, hlm. 161.

${ }^{9} \mathrm{KUA}$ adalah instansi Departemen Agama yang bertugas melaksanakan sebagian tugas Kantor Departemen Agama Kab./Kota di bidang urusan Agama Islam dalam Wilayah Kecamatan. Lihat Peraturan Menteri Agama RI Nomor 11 Tahun 2007 tentang Pencatatan Nikah.

${ }^{10} \mathrm{PPN}$ dijabat oleh Kepala KUA. Lihat Peraturan Menteri Agama RI Nomor 11 Tahun 2007 tentang Pencatatan Nikah.

${ }^{11}$ Neng Djubaidah, Pencatatan Perkawinan dan Perkawinan Tidak Dicatat; Menurut Hukum Tertulis di Indonesia dan Hukum Islam, Sinar Grafika, Jakarta, 2012, hlm. 3. 
tidak tercatat" adalah perkawinan yang sah sesuai syariat (hukum) Islam yang belum didaftarkan, sehingga belum tercatat di KUA setempat.

Selain persoalan pencatatan perkawinan yang diatur oleh UU Nomor 1 Tahun 1974, persoalan batasan minimal usia bagi calon pasangan yang akan menikah masih menjadi permasalahan hampir di sebagian besar wilayah di Indonesia yang disebabkan oleh berbagai alasan. Fenomena ini dikenal dengan perkawinan bawah umur atau nikah dini. Hal ini juga terkendala dengan kewenangan pengawasan administrasi pencatatan perkawinan, yaitu dilakukan oleh Pejabat Pencatat Nikah (PPN) yang berada pada setiap Kantor Urusan Agama (KUA) di wilayah Kecamatan. Sebagaimana ketentuan Pasal 2 Peraturan Menteri Agama Nomor 11 Tahun 2007 tentang Pencatatan Nikah, PPN adalah selaku Pejabat yang melakukan pemeriksaan persyaratan, pengawasan, dan pencatatan peristiwa nikah/rujuk, pendaftaran cerai talak, cerai gugat, dan melakukan bimbingan perkawinan. Terhadap calon pasangan perkawinan Bawah Umur, PPN berperan sebagai lembaga yang mewujudkan tertib administrasi pencatatan perkawinan dengan mengharuskan adanya dokumen penetapan Pengadilan tentang Dispensasi Kawin bagi Calon pasangan bawah umur dimaksud, yang selanjutnya dapat dicatatkan oleh PPN setempat.

Oleh sebab itu, dengan tingginya angka pernikahan dini sebagaimana data yang dikemukakan oleh Subdirektorat Statistik Rumah Tangga, Badan Pusat Statistik Indonesia ${ }^{12}$ dan angka perceraian yang tinggi di Bogor, maka urgen untuk diteliti tentang relasi perkawinan di bawah umur dengan potensi perceraian. Relasi antara perkawinan bawah umur dan perceraian yang terjadi pada pasangan muda tersebut dihubungkan dengan peran dan kewenangan PPN setempat. Hal tersebut ditujukan untuk menilai apakah upaya administratif dapat mengurangi pernikahan bawah umur beserta resikonya.

\section{Rumusan Masalah}

Permasalahan yang akan dikaji adalah Pertama, bagaimanakah kewenangan Pegawai Pencatat Nikah di wilayah Kota Bogor dalam menciptakan tertib

12 Subdirektorat Statistik Rumah Tangga, Op. Cit. 
administrasi terhadap perkawinan Bawah Umur? Pertama, bagaimanakah relevansi antara perkawinan bawah umur dengan tingginya angka perceraian di wilayah Kota Bogor?

\section{Tujuan Penelitian}

Penelitian ini bertujuan untuk mengetahui Pertama, kewenangan Pegawai Pencatat Nikah di wilayah Kota Bogor dalam menciptakan tertib administrasi terhadap perkawinan bawah umur. Kedua, relevansi antara perkawinan bawah umur dengan tingginya angka perceraian di wilayah Kota Bogor?

\section{Metode Penelitian}

Penelitian ini bersifat yuridis-empiris, yaitu dengan melakukan kajian tentang implementasi hukum normatif (undang-undang) mengenai kewenangan PPN dalam menciptakan tertib administrasi pencatatan perkawinan bawah umur terhadap penerapannya pada masyarakat dan oleh stake-holder. Penelitian ini menggunakan data primer, yaitu data yang diperoleh secara langsung dari objek penelitian (field research). Dalam rangkaian penelitian ini, juga dilakukan tahapan wawancara terstruktur kepada Pejabat PPN di lingkungan KUA Kecamatan Kota Bogor guna memperoleh informasi tentang tertib administrasi pencatatan perkawinan terhadap pasangan bawah umur. Peneliti melakukan wawancara dengan majelis Hakim pada Pengadilan Agama Kota Bogor, untuk mengetahui alasan dan pertimbangan hukum hakim dalam mengabulkan permohonan dispensasi kawin, serta alasan hukum pengajuan permohonan itsbat nikah. Selain data primer, penelitian ini menggunakan data sekunder, yaitu berupa literatur/kepustakaan yang berhubungan langsung dengan substansi materi yang ditelaah dalam penelitian ini (library research). Data yang diperoleh, selanjutnya dianalisis dengan menggunakan pola deskriptif analitis untuk dijadikan sebagai kesimpulan.

\section{Hasil Penelitian dan Pembahasan}

Berdasarkan data yang dikeluarkan BPS Kota Bogor dalam proyeksi penduduk atau angka sementara pada 2015 berjumlah 1.000 .000 jiwa. Hingga 
Tahun 2016, angka tersebut sudah mencapai 1.047.922 jiwa. ${ }^{13}$ Menurut keterangan dari BPS, menyatakan bahwa pertumbuhan ekonomi kota Bogor sebanding dengan laju pertumbuhan penduduknya.

Berkenaan dengan fenomena Perkawinan Bawah Umur yang dianalisis pada tulisan ini, sebagaimana didukung oleh data yang dikeluarkan oleh BPS Kota Bogor mengenai Usia Perkawinan Pertama (pada perempuan) masyarakat Kota Bogor dalam kurun 5 tahun terakhir, yaitu dapat dilihat pada berikut:

Tabel 1. Proporsi Penduduk Perempuan Usia 10 Tahun ke Atas yang Pernah Kawin menurut Usia Perkawinan Pertama di Kota Bogor, 2012-2016 Population 10 years and over by the Average age at first marriage in Bogor City, 2012-201614

\begin{tabular}{cccccc}
\hline Umur Perkawinan Pertama/The & \multicolumn{5}{c}{ Tahun/Year } \\
\cline { 2 - 6 } Average age of Forst marriage & $\mathbf{2 0 1 2}$ & $\mathbf{2 0 1 3}$ & $\mathbf{2 0 1 4}$ & $\mathbf{2 0 1 5}$ & $\mathbf{2 0 1 6}$ \\
\hline$(1)$ & $(2)$ & $(3)$ & $(4)$ & $(5)$ & $(6)$ \\
$\leq 16$ & 32526 & 33372 & 31886 & 32312 & 31559 \\
$17-18$ & 55104 & 56425 & 62350 & 64778 & 65086 \\
$19-20$ & 64117 & 66589 & 68336 & 69289 & 71519 \\
& & & & & \\
21 dan lebih & 123212 & 125429 & 126017 & 126142 & 131240 \\
\hline Jumlah/Total & 274959 & 281815 & 288589 & 292521 & 299404 \\
\hline
\end{tabular}

Sumber: Survey Sosial Ekonomi Nasional 2012-2016

Tabel 1 di atas menunjukkan bahwa dalam kurun lima tahun terakhir (20122016), Usia perkawinan di bawah 16 tahun masih berada pada angka yang cukup tinggi, yaitu sebanyak 32.526 orang pada 2012 dan 31.559 orang pada tahun 2016, yang mana tingkat penurunannya rata-rata tidak kurang dari 750 orang per tahunnya, hanya pada 2012, menurun ke angka 426 orang.

\section{Kewenangan PPN-KUA di Wilayah Kota Bogor dalam Menciptakan Tertib Administrasi terhadap Perkawinan Bawah Umur}

Berdasarkan hasil wawancara yang dilakukan dengan Kepala Seksi Bimas

Kemenag Kota Bogor, ${ }^{15}$ memberikan keterangan bahwa pihak KUA di wilayah Kota Bogor telah berupaya mewujudkan tertib administrasi pendaftaran

13 https://www.republika.co.id/berita/nasional/jabodetabek-nasional/16/03/06/o3mlmc282-jumlahpenduduk-di-kota-bogor-membengkak, diakses pada tanggal 31 Juli 2016

${ }^{14}$ Badan Pusat Statistik Kota Bogor, Kota Bogor dalam Angka/Bogor City in Figures 2017, 2017, hlm. 37.

15 Wawancara dilakukan pada tanggal 29 April 2016, di Kantor Kementerian Agama Kota Bogor. 
perkawinan. Terutama dalam melakukan verifikasi data terhadap usia calon pasangan yang akan melangsungkan perkawinan. Selanjutnya, meskipun peraturan perundang-undangan telah memberikan penegasan mengenai batasan usia, melihat fenomena masyarakat akhir-akhir ini, banyaknya terjadi perkawinan bawah tangan yang dilakukan oleh pasangan bawah umur, hal ini sebagai dampak dari pergaulan bebas remaja saat ini.

Perkawinan bawah umur adalah perkawinan antara seorang laki-laki dan perempuan yang keduanya belum mencapai usia 19 tahun bagi laki-laki dan 16 tahun bagi perempuan. Atau dapat juga terjadi dengan kondisi seorang laki-laki berusia 19 tahun dengan perempuan berusia di bawah 16 tahun, atau laki-laki berusia di bawah 19 tahun dengan perempuan berusia 16 tahun. Maka berdasarkan peraturan perundang-undangan yang berlaku, untuk keadaan tersebut di atas, masyarakat dapat mengajukan permohonan dispensasi kawin di Pengadilan Agama setempat. Maka, berdasarkan fenomena masyarakat dimaksud di atas, pihak Kementerian Agama Kota Bogor, dalam hal ini Seksi Bimas Islam, secara berkesinambungan melakukan penyuluhan dan kegiatan kesadaran hukum masyarakat, termasuk di antaranya mengenai pelaksanaan perkawinan secara Islam dengan tanpa mengenyampingkan peraturan perundang-undangan yang berlaku.

Berkenaan dengan kewenangan PPN dalam perwujudan tertib administrasi pencatatan perkawinan, maka terhadap calon pasangan bawah umur (atau salah satu pasangan bawah umur), salah satu persyaratan administrasi pendaftaran pencatatan perkawinan, adalah dengan melengkapi dokumen Akta Penetapan Pengadilan tentang Dispensasi Kawin bagi pasangan bawah umur dimaksud. Sebagaimana Peraturan Menteri Agama RI Nomor 11 Tahun 2007 tentang Pencatatan Nikah, yang menyatakan bahwa 'apabila seorang suami belum mencapai umur 19 tahun dan seorang calon istri belum mencapai umur 16 tahun, harus mendapat dispensasi dari pengadilan. ${ }^{16}$ Dalam Pasal 9 ayat (1) Peraturan Menteri Agama RI Nomor 11 Tahun 2007 tentang Pencatatan Nikah, menyatakan bahwa 'Pemeriksaan Nikah dilakukan oleh PPN atau petugas sebagaimana 
dimaksud oleh Pasal 3 ayat (1) terhadap calon suami, calon istri, dan wali nikah mengenai ada atau tidak adanya halangan untuk menikah menurut hukum Islam dan kelengkapan persyaratan sebagaimana dimaksud dalam Pasal 5 ayat (2)'.

Proses pendaftaran perkawinan yang dilakukan oleh calon pasangan di hadapan PPN, sepanjang memenuhi persyaratan yang ditentukan oleh peraturan perundang-undangan, maka PPN akan menerima serta memproses pencatatan sebagaimana mestinya. Akan tetapi, apabila calon pasangan tidak dapat melengkapi persyaratan adminstrasi yang diperlukan, yang salah satunya adalah dispensasi dari pengadilan bagi calon suami yang belum mencapai umur 19 tahun, dan calon istri yang belum mencapai umur 16 tahun, maka PPN melakukan penolakan kehendak menikah sebagaimana ketentuan pada Pasal 12 ayat (1) Peraturan Menteri Agama RI Nomor 11 Tahun 2007 tentang Pencatatan Nikah, menyatakan bahwa "dalam hal hasil pemeriksaan membuktikan bahwa syaratsyarat perkawinan sebagaimana dimaksud dalam Pasal 5 ayat (2) tidak terpenuhi atau terdapat halangan untuk menikah, maka kehendak perkawinannya ditolak dan tidak dapat dilaksanakan."

Bentuk penolakan nikah dari PPN sebagaimana tersebut di atas, yaitu pihak KUA akan memberikan surat pemberitahuan adanya halangan atau kekurangan atas persyaratan, sehingga para pihak yang berkepentingan dapat segera melengkapinya. Apabila kekurangan berkas dimaksud tidak dapat dipenuhi, maka untuk selanjutnya pihak KUA membuat penolakan atas pendaftaran perkawinan (N-8). Sebagai sampel Data Penolakan Perkawinan dikarenakan Bawah Umur (N8), dapat dilihat pada Tabel 2. berikut ini:

Tabel 2. Jumlah N-8 Penolakan (kurang Umur) Tahun 2015 di KUA Kecamatan Tanah Sareal Kota Bogor

\begin{tabular}{cccc}
\hline No & Tanggal & Nomor Surat Keluar & Nama \\
\hline 1 & $30-01-2015$ & Kk.10.17.06/PW.01/102/2015 & dirahasiakan \\
2 & $20-02-2015$ & Kk.10.17.06/PW.01/170/2015 & dirahasiakan \\
3 & $09-03-2015$ & Kk.10.17.06/PW.01/243/2015 & dirahasiakan \\
4 & $19-03-2015$ & Kk.10.17.06/PW.01/298/2015 & dirahasiakan \\
5 & $14-04-2015$ & Kk.10.17.06/PW.01/408/2015 & dirahasiakan \\
6 & $13-05-2015$ & Kk.10.17.06/PW.01/555/2015 & dirahasiakan \\
7 & $03-08-2015$ & Kk.10.17.06/PW.01/787/2015 & dirahasiakan \\
8 & $31-08-2015$ & Kk.10.17.06/PW.01/901/2015 & dirahasiakan \\
9 & $21-09-2015$ & Kk.10.17.06/PW.01/987/2015 & dirahasiakan \\
\hline
\end{tabular}




$\begin{array}{llll}10 & 22-09-2015 & \text { Kk.10.17.06/PW.01/988/2015 } & \text { dirahasiakan } \\ 11 & 02-10-2015 & \text { Kk.10.17.06/PW.01/1002/2015 } & \text { dirahasiakan } \\ 12 & 22-10-2015 & \text { Kk.10.17.06/PW.01/1051/2015 } & \text { dirahasiakan } \\ 13 & 20-02-2015 & \text { Kk.10.17.06/PW.01/1119/2015 } & \text { dirahasiakan }\end{array}$

Beberapa tahun terakhir ini, Kementerian Agama RI, dalam hal ini Ditjen Bimas Islam, membuat suatu terobosan dalam rangka peningkatan pelayanan publik, memperbaharui paradigma pelayanan KUA di era digital, sekaligus untuk semakin memperkuat penyelenggaraan tertib administrasi perkawinan bagi masyarakat, yaitu pelayanan administrasi nikah berbasis IT, yang disebut SIMKAH (Sistem Administrasi Manajemen Nikah). ${ }^{17}$

Menurut Thobib al-Asyhar, ${ }^{18}$ manfaat yang diambil dengan adanya SIMKAH Online ini, antara lain: Pertama, aplikasi SIMKAH menyajikan tentang data statistik peristiwa nikah seluruh Indonesia bagi KUA yang sudah entry; Kedua, aplikasi SIMKAH bisa memverifikasi data Calon Pengantin (Catin) bagi daerah yang sudah bekerja sama dengan Dinas Pendudukan dan Catatan Sipil (Disdukcapil); Ketiga, pengumuman kehendak nikah dapat dipublikasikan secara luas; Keempat, pendaftaran nikah online segera bisa dilaksanakan.

Penerapan kebijakan Sistem Informasi Manajemen Nikah (SIMKAH) oleh Kemeterian Agama RI ini bertujuan untuk menanggulangi panjangnya prosedur pencatatan nikah. Sistem SIMKAH juga mengurangi identitas ganda, seperti seseorang bisa menikah kedua kalinya dengan identitas yang berbeda. Saat sebuah program atau sistem telah dilaksanakan perlu dilakukan evaluasi. Dari hasil analisis regresi linier berganda diperoleh nilai Fhitung sebesar 10,499, sedangkan $F_{\text {tabel }}$ pada taraf signifikan 0,05 menunjukan nilai sebesar 2,612. Berarti $F_{h i t u n g}>$ dari $\mathrm{F}_{\text {tabel }}$ sehingga Ho ditolak dan Ha diterima, yang berarti variabel bebas mempunyai pengaruh yang signifikan secara simultan terhadap kualitas pelayanan. ${ }^{19}$ Penjelasan atas evaluasi kebijakan SIMKAH di atas, realitanya hampir mendekati

\footnotetext{
${ }^{17}$ http:/ / bimasislam.kemenag.go.id/post/opini/simkah-cara-baru-pelayanan-administrasi-nikah-di-eradigital, diakses pada 03 Agustus 2016

${ }^{18}$ Kasubag Data dan Informasi Ditjen Bimas Islam Kemenag RI, dalam Ibid.

${ }^{19}$ Intania Dwi Permata, "Pengaruh Model Evaluasi Program Cipp Terhadap Kualitas Pelayanan Pencatatan Nikah Berbasis Simkah (Studi Di Kua Kecamatan Taman Dan Kecamatan Gedangan Kabupaten Sidoarjo)”, Jurnal Administrasi Publik, Vol 2, No. 10 (2014), Universitas Brawijaya, Malang. http://administrasipublik. studentjournal.ub.ac.id,
} 
sama dengan penerapan SIMKAH yang ada pada KUA Kecamatan di wilayah Kota Bogor. Meskipun hingga saat ini, mekanisme penerapan SIMKAH tersebut senantiasa terus diperbaharui dan diperbaiki oleh pihak KUA di wilayah Kota Bogor.

Berdasarkan Peraturan Dirjen Bimas Islam No DJ.II/542 Tahun 2013, bahwa bimbingan pranikah atau kursus calon pengantin merupakan bagian dari fungsi KUA. Meskipun dalam pelaksanaanya, belum dapat direalisasikan secara maksimal dikarenakan beberapa faktor. Adapun mengenai pelaksanaan bimbingan pranikah yang diselenggarakan oleh KUA di wilayah kota Bogor yang disebut dengan Suscatin (Kursus Calon Pengantin). Suscatin di 6 KUA, yaitu: KUA Bogor Tengah, KUA Bogor Timur, KUA Bogor Utara, KUA Bogor Selatan, KUA Tanah Sereal dan KUA Bogor Barat. Hampir seluruh KUA menyelenggarakan Suscatin pada hari yang sama, yaitu pada hari Selasa atau Rabu, Suscatin (Kursus Calon Pengantin) berlangsung dari pukul 09.00 s.d. 11.30 WIB, bertempat di ruang Balai Nikah dalam gedung KUA.

Menurut penjelasan yang diperoleh dari Penyuluh di KUA Kecamatan Bogor Selatan,20 dalam rangka mewujudkan sinergisitas antara program KUA dan Pemerintah Kota Bogor, yaitu 'Program 1000 hari kehidupan pertama' bagi bayi, yang ditujukan kepada pasangan suami istri yang baru menikah. Maka dalam pelaksanaan Suscatin, juga mengikutsertakan pihak BKKBN Kota Bogor. Selain materi mengenai 'Program 1000 hari kehidupan pertama', BKKBN juga menyampaikan materi mengenai pentingnya mensukseskan Program KB. Akan tetapi, dalam aktualisasinya, program ini tidak dapat dilakukan secara berkelanjutan, dikarenakan ketidaktersediaan dana dari pihak Kementerian Agama Kota Bogor.

\section{Relevansi Perkawinan Bawah Umur dengan Tingginya Angka Perceraian di Wilayah Kota Bogor}

Berdasarkan data yang diperoleh dari lapangan dan hasil wawancara dengan Kepala KUA dan Penyuluh di lingkungan KUA, bahwa pihak KUA tidak

${ }^{20}$ Wawancara dilakukan dengan Penyuluh KUA Bogor Selatan, pada tanggal 08 Juni 2016, bertempat di ruang KUA Bogor Selatan. 
memenuhi permohonan pendaftaran perkawinan terhadap pasangan atau salah satu pasangan yang berusia di bawah umur menurut undang-undang. Dalam data perkara cerai gugat atau cerai talak di Pengadilan Agama menunjukkan angka yang cukup tinggi. Artinya para pihak yang melakukan pendaftaran perkawinan berbanding lurus dengan data cerai gugat dan cerai talak di Pengadilan Agama Bogor.

Terhadap pasangan yang belum mencapai batasan usia menurut undangundang, maka pihak KUA membuat surat penolakan (N-8), dengan mengarahkan pasangan yang bersangkutan untuk melakukan upaya permohonan Dispensasi Kawin (DK) ke Pengadilan Agama, sebagaimana yang ditegaskan pada Pasal 49 UU Nomor 3 Tahun 2006 tentang Peradilan Agama. Akan tetapi, menurut Kepala KUA Kecamatan Tanah Sareal, ${ }^{21}$ terhadap beberapa calon pengantin yang mendaftarkan perkawinan dengan status bawah umur, setelah disarankan untuk mengajukan Dispensasi Nikah ke Pengadilan Agama, yang bersangkutan tidak pernah kembali lagi ke KUA dengan membawa penetapan pengadilan. Dalam kurun beberapa tahun, hanya ditemukan 1 pasangan yang kembali mendatangi KUA untuk mendaftarkan perkawinannya dengan membawa Penetapan Izin Dispensasi Kawin bawah umur. Hal ini menunjukkan bahwa kesadaran hukum masyarakat terhadap pentingnya pencatatan perkawinan masih relatif rendah, hanya saja ini terjadi apabila telah terjadi hubungan luar kawin yang mengharuskan keduanya untuk dinikahkan.

Selanjutnya Oyo berpendapat, bahwa lazimnya dalam tradisi ajaran Islam, tertib dan tahapan dalam perkawinan adalah melakukan nikah dahulu, baru kemudian kawin. Bukan sebaliknya, kawin dahulu baru kemudian nikah. Jadi, apabila dalam kenyataannya didapati pasangan yang melakukan praktik 'kawin' sebelum nikah, dan menyebabkan kehamilan, maka wanita hamil itu diidentifikasi sebagai 'wanita hamil luar nikah'.22 Sebagaimana pengaturan KHI Pasal 53, yang menyatakan bahwa:

(1) Seorang wanita hamil di luar nikah, dapat dikawinkan dengan pria yang menghamilinya;

21 Wawancara dilakukan dengan Kepala KUA Kecamatan Tanah Sareal, pada tanggal 21 Juni 2016, bertempat di ruang Kepala KUA.

22 Oyo Sunaryo Mukhlas, Pranata Sosial Hukum Islam, Refika Aditama, Bandung, 2015, hlm. 92. 
(2) Perkawinan dengan wanita hamil yang disebut pada ayat (1) dapat dilangsungkan tanpa menunggu lebih dahulu kelahiran anaknya;

(3) Dengan dilangsungkannya perkawinan pada saat wanita hamil, tidak diperlukan perkawinan ulang setelah anak dilahirkan.

Perspektif perlindungan hak kemanusiaan melihat bahwa hakim mengabulkan permohonan dispensasi kawin juga mempertimbangkan atas anak yang akan dilahirkan sebagai akibat dari perkawinan tersebut. Sebagaimana terdapat dalam ketentuan Pasal 53 ayat (2) dan (3) KHI yang menyatakan bahwa apabila terjadi, maka perkawinan dapat dilangsungkan tanpa menunggu kelahiran anak sehingga apabila anak tersebut lahir dan tumbuh sebagaimana biasanya, maka ia ber-nasab23 kepada laki-laki yang menyebabkan kelahirannya.

Pengaturan mengenai pemenuhan hak anak diatur dalam Undang-Undang Nomor 23 Tahun 2002 tentang Perlindungan Anak yang meliputi hak tumbuh dan berkembang, hak sipil dan hak kebebasan, hak pengasuhan dan perawatan, hak bermain dan hak berpartisipasi, hak kesehatan, hak pendidikan serta perlindungan khusus. ${ }^{24}$ Hak anak dalam perkawinan usia dini sebenarnya melihat bagaimana perlindungan hak anak jika dijadikan sebagai subjek dalam perkawinan usia dini, dilihat dari sisi hukum nasional sendiri, melihat sisi sejarah peraturan perundangan tersebut lahir adalah sebagai bukti dari implementasi ratifikasi Konvensi Hak Anak yang bertujuan untuk melindungi kepentingan dan pemenuhan hak di Indonesia.

\footnotetext{
${ }^{23}$ Hubungan Nasab dan Hubungan Darah: kedua istilah ini sering muncul dalam beberapa diskusi tentang hukum perkawinan dan akibat hukum di dalamnya. Menurut Penulis, Hubungan Nasab tidak-lah dapat disamakan dengan hubungan Darah. Meskipun secara istilah sama-sama sebagai akibat dari suatu hubungan hukum perkawinan.

Hubungan Darah adalah hubungan yang memang secara teori ilmu pengetahuan, dan teknologi dapat dibuktikan secara nyata. Yaitu melalui metode tes DNA (deoxyribonucleic acid; dalam bahasa Indonesia dikenal dengan istilah Asam Deoksiribosa Nukleat). Maka, seorang pria yang melakukan hubungan biologis luar kawin dengan seorang wanita, pria tersebut akan memiliki hubungan darah dengan anak yang dilahirkan oleh wanita. Sebatas hubungan darah saja, yang boleh jadi antara pria dan wanita tidak diikat dengan hubungan hukum perkawinan (ijab kabul).

Berbeda halnya dengan Hubungan Nasab, istilah ini dikenal dalam konteks fiqih munakahat, Hukum Perkawinan Islam, bahwa menurut Penulis, hubungan Nasab selain dapat dibuktikan secara teori ilmu pengetahuan, dan teknologi, juga telah lebih dahulu diyakini kebenarannya secara 'transendental' (Muamalah Ma'allab= Hubungan dengan Allah Swt.).

${ }^{24}$ Bagya Agung Prabowo, "Pertimbangan Hakim dalam Penetapan Dispensasi Perkawinan Dini Akibat Hamil di Luar Nikah pada Pengadilan Agama Bantul", Jurnal Hukum IUS QULA IUSTUM No. 2 Vol. 20 APRIL 2013, hlm. 302.
} 
Data pendukung berkenaan dengan jumlah perkara perceraian dan klasifikasi usia para pemohon/penggugat perkara perceraian yang diajukan di Pengadilan Agama Kota Bogor, dapat dilihat pada Tabel 3. dan 4. berikut:

Tabel 3. ${ }^{25}$ Statistik Perkara berdasarkan Usia Pemohon/Penggugat Tahun 2013 s.d. 2016

\begin{tabular}{cccccc}
\hline \multirow{2}{*}{ No } & \multirow{2}{*}{ Usia para Pihak } & \multicolumn{4}{c}{ Tahun (orang) } \\
\cline { 3 - 6 } & $<=20$ tahun & $\mathbf{2 0 1 3}$ & $\mathbf{2 0 1 4}$ & $\mathbf{2 0 1 5}$ & $\mathbf{2 0 1 6}$ \\
\hline 1 & 25 & 261 & 342 & 25 \\
2 & $21-30$ tahun & 431 & 805 & 371 & 431 \\
3 & $31-40$ tahun & 631 & 1222 & 514 & 631 \\
4 & $41-60$ tahun & 393 & 678 & 678 & 393 \\
5 & $>=61$ tahun & 71 & 224 & 87 & 71 \\
\hline
\end{tabular}

Tabel 4. ${ }^{26}$ Statistik Perkara Berdasarkan Jenis Perkara Tahun 2013 s.d. 2016

\begin{tabular}{cccccc}
\hline \multirow{2}{*}{ No } & \multirow{2}{*}{ Jenis Perkara } & \multicolumn{4}{c}{ Tahun } \\
\cline { 3 - 6 } & & $\mathbf{2 0 1 3}$ & $\mathbf{2 0 1 4}$ & $\mathbf{2 0 1 5}$ & $\mathbf{2 0 1 6}$ \\
\hline 1 & Cerai Gugat (CG) & 978 & 342 & 1166 & 1261 \\
2 & Cerai Talak (CT) & 355 & 118 & 176 & 371 \\
3 & Dispensasi Kawin (DK) & 11 & 2 & 4 & 12 \\
4 & Istbat Nikah (IN) & 138 & 128 & 217 & 175 \\
\hline
\end{tabular}

Berdasarkan Tabel 3. dan Tabel 4. di atas, penulis berpendapat bahwa tingginya angka perceraian (cerai gugat dan cerai talak), tidak sepenuhnya terjadi pada pada pasangan berusia 21 - 30 tahun, tetapi juga didominasi oleh pasangan berusia 31 tahun ke atas. Selanjutnya kalaupun perkawinan tersebut 'tidak dicatat', ${ }^{27}$ dikarenakan tidak cukupnya umur menurut undang-undang, masih memberikan peluang bagi masyarakat untuk memperoleh legalitas atas perkawinannya yaitu dengan adanya upaya hukum untuk mengajukan permohonan istbat nikah di Pengadilan Agama.

Penulis berpendapat bahwa, gejala sosial dan fenomena faktual yang muncul di tengah masyarakat wilayah Kota Bogor saat ini tentang pergaulan bebas remaja

25 Webportal Pengadilan Agama Bogor, www.pa-bogor.go.id, dan Webportal Mahkamah Agung RI, www.badilag.net, diakses pada tanggal 31 Juli 2016

${ }^{26}$ bttp:/ / infoperkara.badilag.net/, diakses pada tanggal 30 Juli 2016

27 Perkawinan 'tidak dicatat' mempunyai pengertian yang berbeda dengan 'perkawinan yang tidak dicatatkan' dan 'perkawinan sirr'. Menurut Neng Djubaidah, 'perkawinan tidak dicatat' adalah perkawinan yang memenuhi rukun dan syarat sesuai dengan hukum Islam, tetapi tidak dicatatkan atau belum dicatatkan di KUA Kecamatan, sebagai Unit Pelaksana Teknis Dinas (UPTD) Instansi Pelaksana di wilayah kecamatan setempat, sebagaimana ditentukan dalam UU Nomor 23 Tahun 2006 tentang Administrasi Kependudukan. Lihat Neng Djubaidah, Op. Cit, hlm. 153. 
yang berujung pada terjadinya hubungan luar kawin, dapat dikatakan benar adanya. Akan tetapi berkenaan dengan data pada Tabel 3 dan Tabel 4 di atas, yang dimunculkan oleh pihak Pengadilan Agama Kota Bogor, selaku pemilik kewenangan absolut untuk memeriksa perkara ini, tidaklah sebanding lurus dengan data maraknya perkawinan bawah umur sebagaimana yang tercatat dalam KUA Kecamatan. Hal ini menunjukkan bahwa, tertib administrasi pencatatan perkawinan di lembaga KUA wilayah Kota Bogor telah terpenuhi, serta amanah undang-undang yang diusung oleh Peradilan Agama juga terpenuhi, sehingga atas pencatatan perkawinan bawah umur, tidak dapat dilakukan sebagaimana pencatatan perkawinan merujuk pada ketentuan PMA Nomor 11 Tahun 2007.

Tingginya angka pernikahan di bawah umur ternyata juga sangat memengaruhi angka perceraian pada pasangan usia muda. Sistem perkawinan di Indonesia yang masih permisif untuk perkawinan bawah umur, menjadi celah terjadinya tingkat perkawinan bawah umur yang tinggi. Tabel 4 di atas yang menunjukkan tingginya angka perceraian pada pasangan muda, menjadi alarm atas dampak negatif dari pernikahan bawah umur. Penelitian Mies Grijns dan Hoko Horii di Jawa Barat menunjukkan bahwa 50\% pernikahan dini berakhir dengan perceraian, bahkan ketika usia pernikahannya baru satu atau dua tahun. Hal ini disebabkan oleh ketidakcocokan pasangan dan ketidakmampuan dalam menjalankan rumahtangga secara bersama. ${ }^{28}$ Selain itu, pasangan suami istri usia muda juga belum mempunyai emosi yang stabil sehingga tidak jarang mendorong terjadinya pertengkaran bahkan kekerasan dalam rumah tangga dalam menghadapi persoalan kecil. ${ }^{29}$ Pernikahan membutuhkan independensi dari individu-individu yang menjalaninya, karena penuh dengan tanggung-jawab, pembuatan keputusan dan komitmen yang serius. Akan tetapi pasangan muda yang menikah bawah umur tidak mampu mengatasi hal-hal tersebut. ${ }^{30}$

${ }^{28}$ Mies Grijns dan Hoko Horii, "Child Marriage in a Village in West Java (Indonesia): Compromises between Legal Obligations and Religious Concerns", Asian Journal of Law and Society 5 Maret 2018, diakses melalui https://doi.org/10.1017/als.2018.9, hlm. 8

${ }^{29}$ Djamilah, Reni Kartikawari, 'Dampak Perkawinan Anak di Indonesia', Jurnal Studi Pemuda, Vol. 3 No. 1 Mei 2014, hlm. 13

${ }^{30}$ Sadaf Ahmed, Saima Khan, Malka Alia \& Shamoon Noushad, 'Psichological Impact Evaluation of Early Marriages', International Journal of Endorsing Health Science Research, Vol. 1 Issue 2, Desember 2013, hlm. 85 


\section{Penutup}

Berdasarkan hasil penelitian yang dilakukan, penulis berkesimpulan bahwa pertama, PPN - KUA di wilayah Kota Bogor telah berupaya mewujudkan tertib administrasi pendaftaran perkawinan, terutama dalam melakukan verifikasi data terhadap usia calon pasangan yang akan melangsungkan perkawinan. Hal ini kemudian dipertegas dengan Edaran Kementerian Agama RI perihal pemberlakuan SIMKAH (Sistem Administrasi Nikah) yang semakin mempersempit ruang gerak masyarakat melakukan perkawinan bawah umur. Meskipun peraturan perundang-undangan telah memberikan penegasan mengenai batasan usia, akan tetapi fenomena perkawinan bawah umur masih sering ditemukan di masyarakat. Maka dari itu, dalam rangka menciptakan tertib administrasi perkawinan serta memberikan kepastian hukum atas suatu akad perkawinan, dalam hal dimana calon pengantin pria atau wanita tidak dapat memenuhi persyaratan sebagaimana yang tersebut di atas, maka pihak KUA akan memberikan Surat Pemberitahuan adanya halangan/kekurangan atas persyaratan, sehingga para pihak yang berkepentingan dapat segera melengkapinya. Apabila tidak dapat dipenuhi, maka untuk selanjutnya pihak KUA membuat penolakan atas pendaftaran perkawinan ( $\mathrm{N}-8)$.

Kedua, fenomena maraknya perkawinan bawah umur memiliki relevansi dengan tingginya angka perceraian (cerai gugat dan cerai talak) yang juga didominasi oleh pasangan berusia 21 - 30 tahun, karena kalaupun perkawinan tersebut 'tidak dicatat', disebabkan tidak cukupnya umur menurut undangundang, masih memberikan peluang bagi masyarakat untuk memperoleh legalitas atas perkawinannya yaitu dengan adanya upaya hukum untuk mengajukan permohonan istbat nikah di Pengadilan Agama. Perkawinan bawah umur berdampak terhadap kehidupan rumah tangga masing-masing pasangan. Antara lain timbulnya perselisihan suami istri yang disebabkan karena berbagai faktor, kurangnya kematangan berpikir dan kemampuan menentukan sikap serta tindakan dalam menghadapi setiap permasalahan yang muncul sehingga tidak sedikit pula yang berakhir pada perpisahan dan perceraian. 


\section{Daftar Pustaka}

\section{Buku}

Ali, Muhammad Daud, Hukum Islam: Pengantar Hukum Islam dalam Tata Hukum di Indonesia, Rajawali Press, Jakarta, 2000.

Anshori, Abdul Ghofur, Peradilan Agama di Indonesia Pasca UU Nomor 3 Tahun 2006 (Sejarah, Kedudukan, dan Kewenangan), UII Press, Yogyakarta, 2007.

Badan Pusat Statistik Kota Bogor, Kota Bogor dalam Angka/Bogor City in Figures 2017, 2017

Djubaidah, Neng, Pencatatan Perkawinan dan Perkawinan Tidak Dicatat; Menurut Hukum Tertulis di Indonesia dan Hukum Islam, Sinar Grafika, Jakarta, 2012.

Friedman, Lawrence M, American Law: an Introduction, second edition, W. W. Norton \& Company, New York, 1998.

Mubarok, Jaih (ed.), Peradilan Agama di Indonesia, Pustaka Bani Quraisy, Bandung, 2004.

Mukhlas, Oyo Sunaryo, Pranata Sosial Hukum Islam, Refika Aditama, Bandung, 2015.

Salim HS., dan Erlies Septiana Nurbani, Penerapan Teori Hukum pada Penelitian Tesis dan Disertasi, Raja Grafindo Persada, Jakarta, 2013.

Soekanto, Soerjono, Sosiologi Suatu Pengantar, Raja Grafindo Persada, Jakarta, 2005.

Subdirektorat Statistik Rumah Tangga, Kemajuan yang Tertunda: Analisis Data Perkawinan Usia Anak di Indonesia, Badan Pusat Statistik Indonesia, Jakarta, 2015.

Syarifuddin, Amir, Hukum Perkawinan Islam di Indonesia: Antara Fiqh Munakahat dan UU Perkawinan, Kencana, Jakarta, 2007.

Zuhaily, Wahbah, Figh al-Sunnah wa Adillatuhu, Cetakan ke-VII, Dar el Fikr, Beirut, t.th.

\section{Jurnal Hukum dan Makalah}

Ahmed, Sadaf, Saima Khan, Malka Alia \& Shamoon Noushad, 'Psichological Impact Evaluation of Early Marriages', International Journal of Endorsing Health Science Research, Vol. 1 Issue 2, Desember 2013, hlm. 85

Djamilah, Reni Kartikawari, 'Dampak Perkawinan Anak di Indonesia', Jurnal Studi Pemuda, Vol. 3 No. 1 Mei 2014, hlm. 13

Grijns, Mies dan Hoko Horii, "Child Marriage in a Village in West Java (Indonesia): Compromises between Legal Obligations and Religious Concerns", Asian Journal of Law and Society 5 Maret 2018, diakses melalui https://doi.org/10.1017/als.2018.9

Lutfiyah, Zeni, dkk., "Perkawinan Siri dalam Reformulasi Hukum Perkawinan Islam di Indonesia sebagai Upaya Preventif terhadap Disharmoni Sosial 
dalam Masyarakat (Perspektif Gender dan Hak Asasi Manusia)", Jurnal Hukum Yustisia, Edisi 91, Januari - April 2015, Fakultas Hukum Universitas Sebelas Maret, Surakarta.

Permata, Intania Dwi, “Pengaruh Model Evaluasi Program Cipp Terhadap Kualitas Pelayanan Pencatatan Nikah Berbasis Simkah (Studi Di Kua Kecamatan Taman Dan Kecamatan Gedangan Kabupaten Sidoarjo)", Jurnal Administrasi Publik, Vol 2, No. 10 (2014), Universitas Brawijaya, Malang. http:/ / administrasipublik.studentjournal.ub.ac.id.

Prabowo, Bagya Agung, "Pertimbangan Hakim dalam Penetapan Dispensasi Perkawinan Dini Akibat Hamil di Luar Nikah pada Pengadilan Agama Bantul", Jurnal Hukum IUS QUIA IUSTUM NO. 2 Vol. 20 APRIL 2013, UII, Yogyakarta.

Sururie, Ramdani Wahyu, "Kekuatan Pembuktian Testimonium De Audito dalam Perkara Perceraian (Kajian Putusan Nomor 0141/Pdt.G/2011/PA.Krw dan Nomor 16/Pdt.G/2012/PTA. Bdg", Vol. 7 No. 2, Jurnal Yudisial, Komisi Yudisial, Jakarta.

Yumarni, Ani, "Kesadaran Hukum Masyarakat terhadap Mediasi dalam Perkara Perceraian Berdasarkan PERMA Nomor 01 Tahun 2008 (Studi Kasus pada Pengadilan Agama Kota Bogor)", Hasil Penelitian dalam Hibah Dosen Pemula DIKTI, Universitas Djuanda, Bogor, 2014.

\section{Peraturan Perundang-undangan}

Undang-Undang Nomor 1 Tahun 1974 tentang Perkawinan (Lembaran Negara Republik Indonesia Tahun 1974 Nomor 1)

Undang-Undang Nomor 7 Tahun 1989 tentang Peradilan Agama (Lembaran Negara Republik Indonesia Tahun 1989 Nomor 49, Tambahan Lembaran Negara Nomor 3400)

Undang-Undang Nomor 3 Tahun 2006 tentang Perubahan atas Undng-Undang Nomor 7 Tahun 1989 tentang Peradilan Agama (Tambahan Lembaran Negara Republik Indonesia Nomor 4611)

Undang-Undang Nomor 50 Tahun 2009 tentang Perubahan Kedua atas UndngUndang Nomor 7 Tahun 1989 tentang Peradilan Agama (Tambahan Lembaran Negara Republik Indonesia Nomor 5078).

Undang-Undang Nomor 23 Tahun 2006 tentang Administrasi Kependudukan (Tambahan Lembaran Negara Republik Indonesia Nomor 4674)

Peraturan Menteri Agama (PMA) Nomor 11 Tahun 2007 tentang Pencatatan Nikah (Berita Negara Republik Indonesia Tahun 2007 Nomor 5)

\section{Sumber Lainnya}

Webportal Mahkamah Agung RI, www.badilag.net, diakses pada tanggal 31 Juli 2016 http://infoperkara.badilag.net/, diakses pada tanggal 30 Juli 2016 
Webportal Pengadilan Agama Bogor, www.pa-bogor.go.id diakses pada tanggal 31 Juli 2016

http:/ / bimasislam.kemenag.go.id/post/opini/simkah-cara-baru-pelayananadministrasi-nikah-di-era-digital, diakses pada 03 Agustus 2016

Website resmi Kemenag RI, http://bimasislam.kemenag.go.id diakses pada tanggal 26 Juni 2014

https:/ / www.jpnn.com/daerah/jabar 09 Maret 2014

www.republika.co.id, diakses pada tanggal 31 Juli 2016

https://bogorkota.bps.go.id/linkTabelStatis/view/id/15, diakses pada tanggal 30 Juli 2016 